\title{
CHALLENGES IN THE CENTRAL EUROPEAN POSTAL MARKETS: THE EXAMPLE OF THE POLISH POST
}

\author{
Czarniewski, S.
}

The purpose of this work is to show the economic conditions of the postal market in Poland. The pace of economic transformation and growing competition in the postal market means that Polish Post is somehow forced to take new measures to improve the effectiveness of communication with their market environment. The focus points of this study are the economic mechanisms of the effectiveness and efficiency of the process of communicating specified value to the customer, and an attempt to identify the factors boosting an increase in efficiency. The reflections contained in the paper do not have definite characteristics and should be treated as an opinion in the discussion.

JEL Classification: M31, M37

Keywords: postal market; communicating value; competition; customer.

\section{Introduction}

The system transformation of 1989 changed the economic reality of Poland. An economic consistency is that economic growth leads to the development of the service sector, including postal services (Dokurno, 2008, pp. 23-27). The development of the postal services market is a consequence of changes in the global economy, in which the issue of communication takes on fundamental importance. Postal services aim to meet the needs of consumers in the transmission of information over distance, allowing the development of other sectors of the national economy.

In recent years the market for postal services has grown rapidly, and with it the growing needs and expectations of customers. The development of electronic communication techniques, increasing competition, and increasing consumer demand for postal services have a direct and indirect impact on the behavior of entities operating in the postal market, which in turn affect the quantity, quality and value of postal services.

\section{Research Methodology}

One method used in this paper is descriptive analysis based on extensive study of subject literature. Polish and foreign, mainly English-language, literature on economic issues connected with communicating customer value were used to support the theoretical part of the work. The use of foreign literature proved to be necessary because of insufficient Polish studies. This enriched the arguments and discussion of new aspects, and helped reveal the research problem in a broader perspective. The paper contains confrontation of theory and practice - an analysis of the mechanisms of the postal market in Poland.

Empirical considerations were based on studies conducted on postal institutions as well as the author's own research. Analysis of the research results carried out by foreign entities was conducted to provide information as to the overall development of business communication systems with the market. The author's own research should expand the knowledge available on aspects relating to the effectiveness and efficiency of the process of communicating customer value and should be a starting point for broader comparisons and conclusions.

\section{The Main Changes on Postal Market in Poland}

The transformation of the postal sector has been influenced by many factors, most importantly by the dynamic development of electronic communication techniques, amplified by the convergence of telecommunications and other electronic media. For postal operators, it is imperative to know the impact of ICT (Information and Communication Technologies) on the development of the market in terms of competition and convergence of the postal services market (Magdzicka, 2008, p. 241).

The nature of the postal service is derived from its strategic importance in the economic activities of countries and its importance to society. Postal services 
are linked to other segments of business (electronic communication, transportation, logistics, marketing activities), and many segments are associated with postal service infrastructure (e-commerce, financial services, government administration etc.).

The services provided by postal operators, which include ensuring full spatial accessibility at a socially acceptable price, do not correspond to the notion of a public good. Under such circumstances, universal postal services can only be qualified as a mixed good, as in both the production process of mail considered as a whole, as well as in its breakdown into basic fragments (collection, sorting, transport and delivery), there is no application or principle of non-exclusion, and it is not non-rivalrous in consumption (Buko, 2008, p. 251). Almost every seasonal intensification of demand for delivery services causes periodic failure of the postal system, resulting in diminishing marginal utility because of the unmet needs of all customers ${ }^{1}$. Therefore, these universal services are not conceptually identical to public services (goods), although public authorities take responsibility for financing the cost of their provision.

Economic theory argues that when the maintenance costs of public enterprises are lower than the value of the public benefits obtained, such activities shall be admitted as a necessary function of government (Lipowski, 2002, p. 178).

From the point of view of society, there is a consensus that it is socially important for every customer to have access to postal services; in practice, however, the state does not attempt to consult the beneficiaries of these services, unjustifiably assuming that the individual recipient does not have sufficient knowledge to assess the benefits of the consumption of these services (Labedz \& Lee, 2011, pp. 56-76). The scope of provision of universal services is therefore discretionary and decisions on the inclusion of selected postal services are political in nature ${ }^{2}$.

The interest of the state in this field of economic activity is reflected in the separate laws governing the operation

1 Some customers, aware of the failure of the Polish Post to meet declared delivery deadlines, resigned from the use of their postal services.

2 This view, in relation to current communication services, is shared by German researchers, which is reflected, inter alia, in the studies of: W. Eisenbast, Universaldienst unter Wettbewerb, Ökonomische Analyse neuer regulierungs - politischer Ansätze zur Sicherstellung der postalischen Infrastrukturversorgung, Nomos Verlagsgesellschaft, Baden-Baden 1999 and Ch. Gabrisch, Universaldienst in Deutschland - Neukonzeption für einen liberalisierten Telekommunikationsmarkt, Deutscher Universitäts - Verlag, Wiesbaden 1996. of the postal services market, the appointment of regulators with expertise in influencing postal operators and determining the scope of postal services on the principles of universality (Panasiuk, 2003, p. 69).

Polish Post S.A. is one of the largest service companies, both in Poland and in Central and Eastern Europe. In addition, this enterprise is the national operator in Poland in terms of universal postal services.

Currently, Polish Post S.A. is a typical network enterprise operating throughout the country, employing approximately 85000 employees. The size of the company (in physical and human capital), the organizational structure, and the management style have a good basis on which to carry out detailed research and analysis on the efficiency and effectiveness of actions taken by the company. This is often a source of valuable information for making certain decisions and thereby improving enterprise management systems.

Until the end of the 1980's, the needs of the population, as well as companies and institutions, in the field of postal services, were met by the Polish Post, which had exclusive rights to the provision of those services. After 1990, there was a period of gradual liberalization of the postal market, with a systematic increase in the number of entities involved in this type of activity, and a rapid growth in this segment of service provision has been recorded since 1996.

The success of many companies in the market are increasingly determined by timing, flexibility of actions among partners, and the rapid transfer of information concerning specific value for the customer (Cascio, 2005, pp. 159-163). Therefore, it becomes essential to invest in effective communication. For Polish Post S.A. this is a special challenge, because it has come to exist and operate in a competitive market, where the telephone, fax, and e-mail greatly cater to the immediate needs of customers, especially those with higher incomes. Under such market conditions, the recipient is the most important, since he has the freedom of choice and is not restricted in any way. Service providers (including Polish Post S.A.) are in a much more difficult situation, and are forced to constantly fight for customers, encouraging them to make a purchase by using a variety of communication activities (e.g. advertising, personal selling, sales promotion).

Since the mid-nineties, the Polish postal market has been functioning under conditions of gradual liberalization. On the one hand, the scope of services reserved for the public operator has decreased, on the other, new entities are systematically appearing that are active in the provision of postal services. At the end of 2007, apart 
from the Polish Post, 164 entities were registered as postal operators. Not all operators which have obtained a certificate with the register of business activities are actually operating (in fact only about 60 entities are in operation) (Report, 2008, pp. 13-14). Before the liberalization of the market, any activity of the Polish Postal Service in the area of promotion, whether in terms of service, or the company itself, were generally minor. However, with the current situation of strong competition in the market, promotional activities have become an indispensable element of marketing for the Polish Post.

Z. Mikolajczyk states that the change in economic conditions stems not only from the pressure national companies operating in a given market exert on one another, but also from various events which have a global dimension (Mikołajczyk, 2003, pp. 23-24). This includes the deregulation and liberalization of markets, and the year to year increase of new products, in terms of quality, technology and manufacturing techniques. These phenomena undoubtedly affect the functioning of the Polish Post.

The conditions in which a public postal operator functions in the market are designated by the purchaser of the service. This happens through the economic and social transformation of consumer behavior in terms of lifestyle, attitude, characteristics, needs, demands and preferences (Martin, 2010, pp. 58-65). This changes the role of consumers to one of market participants, who have become as powerful as the state in bringing about market transformation (Rucińska, 2001, p. 81).

The specificity of the activities of the Polish Post has also been conditioned largely by the transformation of an industrial society into an information society, which increases the demands of the customer in relation to the services offered by the postal operator. Often these requests are related to technological developments, forcing the expansion of the existing range of services provided by the Polish Post, the implementation of which requires the use of modern technology (Kotylak, 2008, p. 346).

In recent years, the management system of the Polish Post, and its internal communication process, has raised many doubts. Executives at several levels have lost sight of the main goal, which is to achieve a profit. Managers are deprived of information about the actual financial results of the units they are in charge of. They receive only fragmented information about goals and limits that have been reached. In many cases, rather than working towards cost optimization, various processes caused the opposite - the deteriorating profitability of the company, by focusing on the implementation of tangible tasks, irrespective of the costs incurred with the quest for full utilization of cost limits. In practice, information on the financial results of the company is available only at the central headquarters of the Polish Post.

The Polish Post, rather than improving services and striving to meet the needs of customers, has for many years focused on internal processes. This has led to a significant reduction in the quality of services in both the timeliness and security of deliveries. As a result, a large group of existing customers have turned to other operators. This situation has caused a loss in sales revenue, worsening the financial situation of the enterprise, thereby worsening the efficiency of business activities (Pokora, 2008, p. 451). The example of the Polish Post is proof of how disregard of the theoretical foundations of economics has led to serious problems for one of the largest enterprises in the country.

\section{The Impact of Modern Technology on the Postal Process of Communication}

The computerization of society has given customers access to market information and has increased the ability to process this information on an unprecedented scale. The increased affordability of knowledge that consumers desire (including competitors' offers) is both an opportunity and a threat for a growing number of companies (including the Polish Post). Business activities of enterprises aiming to adapt to changes in the market must take into account solutions in the area of knowledge management. One indicator of the effectiveness of knowledge management can be, and often is, the ability to attract and maintain loyal customers (Kowalczyk \& Nogalski, 2007, p. 44). These aspects are also very important for postal operators.

New technologies determine the direction of business activities of postal operators. New postal services, generated by the changing needs and expectations of economic entities and societies, are dedicated strictly to a separate group of users who precisely define their requirements (services called ,targeted, tailored, timely") (Stolarczyk, 2006, p. 64). This approach to service offerings creates an opportunity to gain a strong position by those among postal operators who are rapidly and increasingly using modern technologies.

Polish Post S.A., in order to improve their business activities, has implemented a central, unified computerized system. The use of this system will allow authorized persons to access information about services registered in the system and greatly simplify the management of services from the position of the central level of the Polish Post. It will also increase the 
efficiency of using information technology (GądekHawlena, 2003, p. 27).

A major innovative project based on the use of electronic communication techniques was the recent implementation of an Integrated ICT System. This system is equipped with computer network software that enables the management of postal cargo by providing everyone involved in the postal transportation process with information about the progress of the delivery. The Integrated ICT System eliminates the need for paper records through electronic data interchange, which increases the effectiveness of process management. Electronic tracking of registered mail from the moment it is sent to the moment of delivery provides clients with access to information about their package. It should be noted that this system was introduced quite late compared to other companies.

The services offered by the Polish Post to communicate value for the customer are not broad. On their website, the national postal operator presents basic information about their business and their services, provides interactive price lists and forms used to provide postal services ("mail sent" book, address labels) and an index of postal address numbers allowing a search for particular post offices, postal codes, etc. Online services offered by the Polish Post include: ordering a courier to pick up a package, and the ability to track it, as well as ordering mail subscriptions of periodicals.

In order to provide customers with information about their services, a call center has been created - a postal center of information and consultation for basic postal services as well as a helpline dedicated to the courier service Pocztex / EMS (Magdzicka, 2008, pp. 243).

In cooperation with Postal Bank S.A. (an entity whose main shareholder is the Polish Post) the Polish Post mediates the offering and implementation of electronic banking services such as credit and on-line deposits. The Postal Bank also offers access to one's bank account through the Internet, with the possibility to make transfers and payments, as well as passive access to the account via a mobile phone (to check account balance), etc.

POS terminals have been installed in some post offices. They allow one to make cash withdrawals from credit cards ("window teller" service). It should be noted that customers trying to use these services often encounter significant problems (due to the fairly frequent failure of these devices).

The Polish Post does not have much experience in e-commerce. The market share of the national operator in this regard is negligible. In recent years, postal offices in Szczecin carried out the sale of textbooks, calendars and dictionaries on a national scale. The offer was addressed mainly to students and schools in low-urbanized areas. However, the scale of these sales, and thus revenues, were not significant for the Polish Post. The growth of e-commerce in many markets generates the need for the delivery of goods. This is where postal services (packages and registered mail) can play an important role as a platform for communication and commerce.

In recent years, in response to changes in the market, Polish Post S.A. introduced e-delivery. Clients learn of the arrival of mail by means of SMS or e-mail. The service is aimed at those who want to receive parcels in a post office chosen they choose (Stefanek-Dziadosz, 2009, p. 491). This offer is primarily intended for customers of online stores, mail order companies and individuals who, for various reasons, would like to pick up their order at the post office. There is no doubt that this product was introduced to the market too late.

In a few regions of Poland, in cooperation with the local government, the Polish Post has launched social communication centers, where postal services are combined with a rural library and Internet café all in one place. These centers not only provide a variety of services, but also serve an educational and communicative role, facilitating contact between residents of less urbanized areas and service providers, customers and suppliers, and the public authorities. There are only a small number of such centers (in 2008 there were only 31 in the whole country), which indicates the marginal extent of this segment of services offered by the Polish Post, and a minimal in relation to social needs. Without developing activities in this field, the Polish Post will lose the chance to fulfill their social mission and create a positive image for the company. It should also be noted that in many countries of the European Union, local postal and telecommunication centers have been in operation for many years, successfully fulfilling its variety of functions, including those of market communication.

The above examples indicate the considerable distance of the Polish Post to leading European public postal operators in the use of new technologies, analogous to the gap between the Polish economy and the economies of developed countries of the European Union. Activities that are innovative for the Polish Post are considered standard among leading postal operators, particularly in the use of new technologies in logistics and services. Catching up to other countries in this area requires a large financial investment, but also the reorganization of the company and the creation of a new organization culture (Kumar \& Shah, 2009, pp. 119-136). 
More and more organizations are using digital technologies to create and process mail. The mailing of original paper documents has been replaced by digital transfer. In many countries, government institutions accept digital (electronic) documents in legal and tax processes (Kobus, 2009, p. 577).

These changes in the information society mean that there is a necessity to modify the offer of the Polish Post due to the gradual disappearance of traditional delivery service. Paper shipments will be scanned, and its digital form shall be delivered to the addressee (hybrid mail). This service is dedicated to communication between public authorities and other entities or persons. Hybrid mail services fall within the area of e-government, and enable an increase in efficiency of the administration. Use of the service is also beneficial for large commercial organizations, which may collect orders and issue invoices via this route.

It is a good idea to look for solutions which have already been tested and used by other postal operators. Hybrid mail also includes changing e-mail messages into traditional correspondence. For example, the Swedish Post does not limit this service to business customers only, but offers it to individual customers as well. Customers can send a letter in an e-mail to the post office, where it is printed, inserted in an envelope, and delivered to the recipient (Gogołkiewicz, 2008, p. 630). This service is especially useful in the case of mass mailings. The customer does not have to worry about having to bring the correspondence to the post office. An additional service is the ability to choose the place from where the shipment is sent.

The activities of the Polish Post are a visible attempt at becoming a modern enterprise. They show the creativity of the public operator on the postal market, but are certainly not sufficient to meet the needs of projects implemented chronically, such as the implementation of an information system or of new e-service products (Stańczak, 2008, p. 527). In comparison with Western European administrations, it remains far behind in the development of innovative processes and services. When it comes to cooperation with the Information Society, there is no basis to conclude that the differences in the functioning of the Polish Post and its counterparts in other countries of the European Union will be reduced any time soon.

Active and systematic use of electronic communication techniques by postal operators in Europe to innovate services and processes has allowed them, to some extent, to avoid the threat of substitution in the letter mailing segment, as well as has allowed them to take advantage of the opportunities offered by the Internet and the specific needs of customers in the package segment (Stolarczyk, 2007 , p. 370). The above considerations show that many public postal operators adopted the expansion of new electronic communications services wholeheartedly, using them to upgrade existing services and to offer new ones. The development of e-commerce, the implementation of e-products, the introduction of an e-government platform, launching a virtual post office, allowing the possibility to prepare a letter using one's own computer and the software of the Polish Post, the use of the company's brand name, which is associated with security, for the implementation of electronic signature certification services, seem to be powerfully relevant recommendations for the Polish Post in terms of development of new technologies.

\section{Communication with the Environment as a Form of Image Creation}

Company image is formed slowly and once fixed (not always positively) it is difficult to improve it. This requires decisive, long-lasting and consistent behavior across the enterprise. Important here are the activities of communication. The deterioration of the image does not occur abruptly, but it is much easier to do. Once rendered in the wrong direction, it can nullify the effect of many years of reliable service (Gamble, Napp, Marsella \& Stone, 2005, pp. 35-46).

The vast geographical range of the company, the provision of an unusually wide range of services, and its enormous human resources compel the Polish Post to use all available means of marketing communication. Promotional tools are used in a thoughtful manner, taking into account the current needs of the company and its financial capabilities.

The Polish Post carries out many promotional activities using their own existing tools. Leaflets and direct mail are delivered by postmen and are also often issued at post office windows. Posters and billboards are displayed inside and outside post offices. The Polish Post webpage is more and more frequently used to disseminate information about current sales and other information about the company. Radio advertising, television and press releases are used to promote the services of the Polish Post. Adverts in trade magazines (the weekly "Polish Post", internal regional corporate publications) are addressed directly to employees, informing them about the full range of internal sales promotions. The Polish Post refrains from placing their ads in general magazines and newspapers.

For many years, the Polish Post has organized various competitions, such as "Letter Writing" week, Valentine's 
Day, writing letters to Santa Claus, and many other activities for customers of different age groups. Sales promotions are also geared to employees, such as consumer loans on favorable terms, suitable bonuses for the achievement of sales or of specific tasks, as well as the organization of contests with prizes for employees (Buko, 2007, pp. 530-531).

There have been symposia and conferences organized successively at the University of Szczecin on the topic of problems of the postal services market. The company organizes museum, philatelic and painting exhibitions, and participates in social and charity projects (Ryan, 2011, pp. 34-42). It co-organizes events such as "A Postcard to Santa Claus", "Quit smoking with us," the Great Orchestra of Christmas Charity, charity actions for people affected by disease, and aid to victims of natural disasters; these are just a part of the activities in which this enterprise had been involved, using each occasion to meet with representatives of the media. The activities mentioned above are, to a certain extent, directed to the company's employees.

Within the Polish Post, there direct sales units (commercial units) which offer postal services to contractual customers. There is a network of sales representatives who offer postal products and services, as well as insurance services. There is also a network of intermediaries who sell credit and insurance services. Personal selling is also carried out by staff operating windows, postmen and other service workers. There are frequent cases of the sale of products belonging to different entities of the Polish Post's "capital group" by the same employee who is simultaneously: mailman (through a contract of employment with the Polish Post) and agent (through a service contract with the Postal Agency of Financial Services S.A.).

The financing of sport and culture ensures publicity, as well as a much-needed addition to Public Relations. This type of communication is realized in the field of sport by sponsoring the Polish Olympic Committee, and ski jumper Adam Malysz in the past, in the field of culture by providing financial support to: The Festival of Four Cultures in Lodz, Avenue of the Stars Festival in Międzyzdroje, "Wieniawski" Violin Festival and Country Picnic in Mrągowo, Festival of Contemporary Music, and the long-term cooperation with the Grand Theater and Polish National Opera.

The quality of the fulfillment of the mission "Every day for you...", which the Polish Post has set for itself, can be measured, inter alia, through the quality of the relationship with its environment. The more the management of the company, and its other members, are interested in the situation of the internal and external environment, and have current data concerning the environment, the better they can fulfill this mission, the higher their satisfaction with the activities carried out, and the greater the benefits to those to whom the company's operations are addressed to. The Polish Post claims to have an active information policy, working with the media and publishing information exactly where potential partners, collaborators, clients and employees look for it. The failure to complete these activities can lead to alienation from the environment, difficulty in developing the enterprise and its human capital, and a loss of recognition and social capital.

The Polish Post has the means to conduct promotional activities using their own resources, through personnel who have direct contact with the buyer (recipient). It also has facilities, such as post offices and mailboxes, through which they can advertise services and impact the image of the operator, as well as communicate within the company through bulletin boards for customers and employees.

The Polish Post uses various promotion elements: leaflets, posters and occasional television advertising. Through its engagement in charity and sponsorship, the Polish Post shapes its image, which affects clients' decisions to use their postal services, as well as employees' identification with the company, and pride in their jobs. Verbal relations between: customer - customer, customer - employee, employee - customer, employee employee, which have a positive nature, can do more for the company than any other activity that require payment (Šikýř, 2013, pp. 43-48).

The Polish Post is not only an entity which uses advertising to promote its business, it is also a provider of advertising space (providing space on the windows and interior walls of the post office for advertising purposes). The personalized stamp is an offer by the Polish Post that fits well into the process of communicating specific value for the customer. People may design their own postage stamps, which are delivered electronically, with the image printed on part of a traditional postage stamp. This additional printed element can be used for promotion of a person or company. A customer can use the personalized stamp to pay the fees for postal services of the Polish Post, or treat it as a philatelic item to collect. People are the main factor of the marketing activities used to develop the market potential of the Polish Post; therefore many activities are directed precisely to employees. The staff is responsible for the creation of a proper image of the company among the public, especially operational staff who are in regular contact with 
service users, and through this contact can create positive or negative impressions of the company. The workforce is divided into groups of employees who are very active in marketing activities, and those who do not engage in marketing their company. The first group performs their duties better, and at the same time impacts the relationship of the company with the environment, and in many cases also shapes mutual employee relationships within the company (Czarniewski, 2014, pp. 10-28).

The last important instrument of marketing is customer service. Proper preparation and courtesy of staff create the right conditions to service clients efficiently and amiably. Clients' positive feelings associated with the service will contribute to re-use of the services of the Polish Post. The quality of service is primarily dependent on the qualifications, competence, and commitment of personnel, and their belief in their own abilities, as well as the enforcement of regulations.

Table 1: The growth rate of the number of private postal operators in Poland in years 1996-2011

\begin{tabular}{|c|c|c|c|}
\hline Year & $\begin{array}{c}\text { The number } \\
\text { of registered } \\
\text { operators }\end{array}$ & $\begin{array}{c}\text { The increase in the number } \\
\text { of operators in relation to the } \\
\text { previous year }\end{array}$ \\
\hline 1996 & 15 & & \\
\hline 1997 & 17 & +2 & $13 \%$ \\
\hline 1998 & 18 & +1 & $6 \%$ \\
\hline 1999 & 21 & +3 & $17 \%$ \\
\hline 2000 & 21 & 0 & $0 \%$ \\
\hline 2001 & 30 & +9 & $43 \%$ \\
\hline 2002 & 52 & +22 & $73 \%$ \\
\hline 2003 & 58 & +6 & $12 \%$ \\
\hline 2004 & 90 & +32 & $55 \%$ \\
\hline 2005 & 113 & +23 & $26 \%$ \\
\hline 2006 & 157 & +44 & $39 \%$ \\
\hline 2007 & 164 & +7 & $4 \%$ \\
\hline 2008 & 182 & +18 & $11 \%$ \\
\hline 2009 & 209 & +27 & $15 \%$ \\
\hline 2010 & 244 & +35 & $17 \%$ \\
\hline 2011 & 247 & +3 & $1 \%$ \\
\hline
\end{tabular}

Source: Author's own research based on the reports of the President of the Office of Electronic Communications in 2009, the Office of Electronic Communications, Warsaw 2010, pp. 108-109; reports of the President of the Office of Electronic Communications in 2010, the Office of Electronic Communications, Warsaw 2011, pp. 53 and based on the reports of the President of the Office of Electronic Communications in 2011, the Office of Electronic Communications, Warsaw 2012, p 60.
The constantly increasing number of operators interested in providing postal services pose new challenges for Polish Post S.A. in communicating specific values in all desired directions and using all tools and channels sufficiently to communicate with the environment in accordance with its expectations. Particularly important is the intensification of communication in the face of ever growing competition.

Particularly high growth in the annual quantity of entities interested in providing postal services has been recorded since 2001. Table 1. shows the number of registered private postal operators in Poland in years 1996-2011. In the years 1996-2011, there was more than a 16-fold increase in the number of private operators (from 15 to 247 operators). The largest percentage increases compared to the preceding year were recorded in $2002(+73 \%)$ and $2004(+55 \%)$. Thus, intensifying competition in the market is rather forcing the Polish Post to take action to improve the effectiveness of the process of communicating customer value.

A nationwide survey conducted among employees of the Polish Post in 2008 showed similar results and / or trends as obtained in the author's own research. Employees indicated colleagues, ordinances, official documents, and superiors as the best sources of information (Figure 1).

The survey from which this data was taken was carried out at the request of the Directorate-General of the Polish Post, and concerned employee opinion on various aspects of operations and communications of the Polish Post. Based on this research, it was found that none of the 14 listed sources of information was used "very often", and the dominant majority, or $71,4 \%$ of the sources indicated, was used on a scale from 3,0 to $4,0 \%$, that is, at frequencies between "rare" and "sometimes".

Figure 2 shows how well informed employees of the Polish Post feel. The results of the study indicate that $39 \%$ of workers do not feel sufficiently well informed about the situation of the company, and about what is happening within it.

The progressive liberalization of the market and a shrinking demand for traditional postal services require the strengthening of marketing and communication activities directed primarily to the largest customers of 'the capital group' of the Polish Post, as well as to the youngest part of the population, which is most likely to use substitute services with respect to postal services, based on modern electronic and telecommunication technologies (Internet, telephone).

Developing a positive image is associated with visual identification. For a company like the Polish Post, this is a special challenge that is only possible to achieve 
Figure 1. The effectiveness of communication channels, according to nationwide research

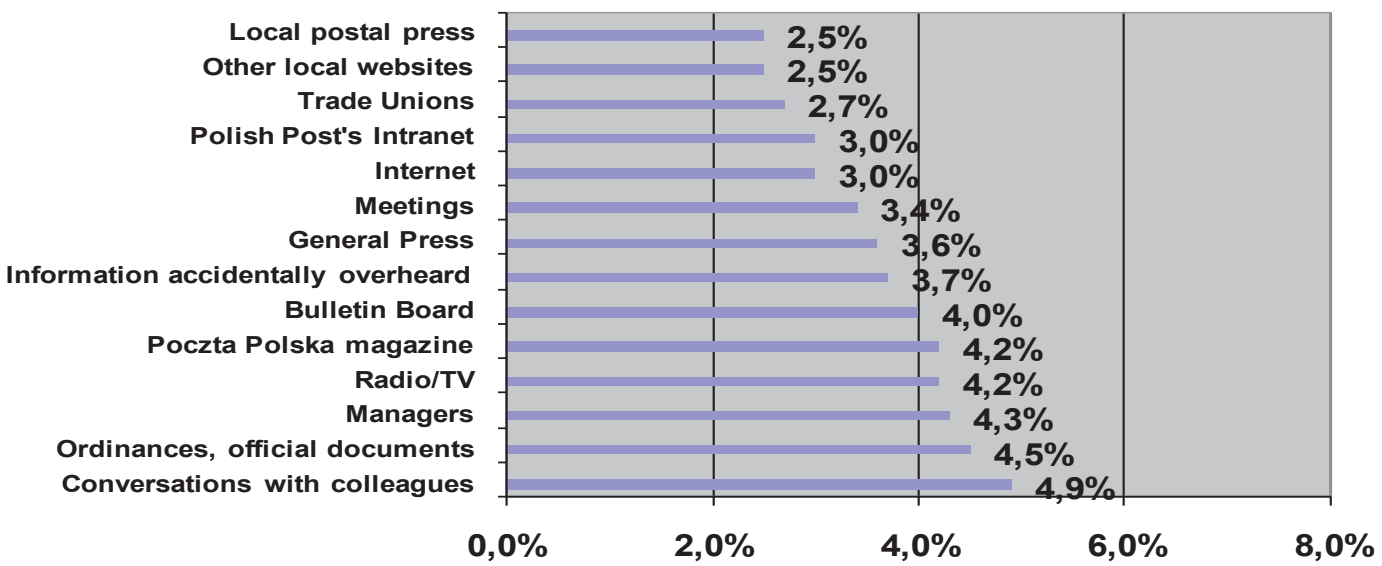

Source: Author's own research based on Grzymisławska, J. (2008). Opinion poll, Polish Post, No. 5, February 4.

The most valued source of information turned out to be conversations with colleagues, which were rated higher than ordinances and official documents. The author's commentary on the research indicated that low frequency of the use of the Internet and intranet sources was a result of limited access to computers.

Figure 2. Postal employees' level of awareness about what is happening within the company

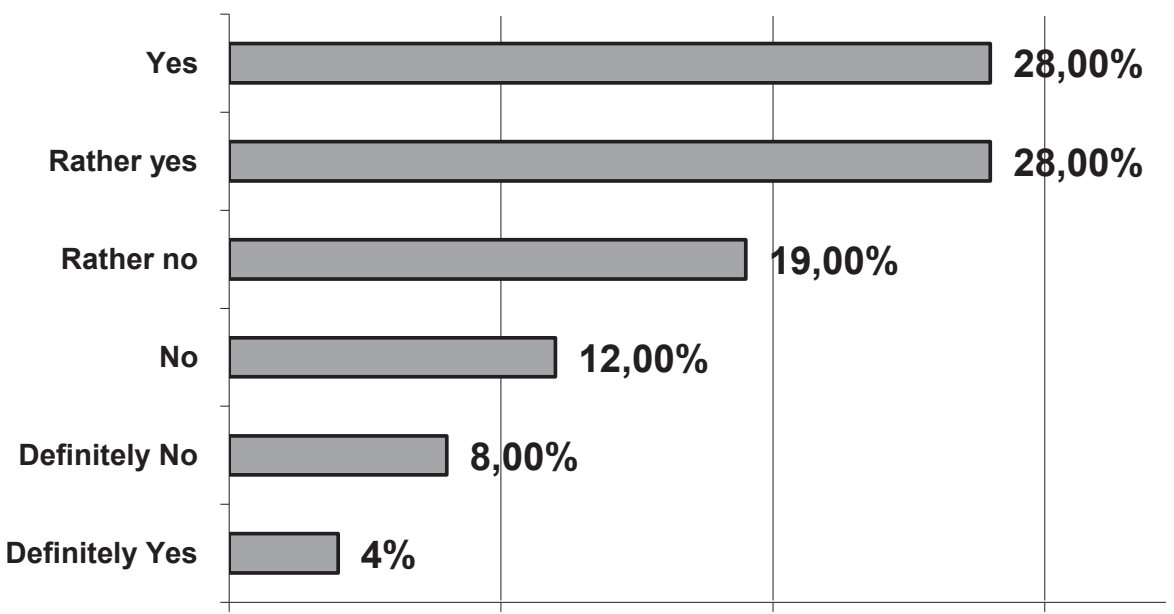

Source: Author's own research based on data from national surveys conducted for the DirectorateGeneral of the Polish Post.

through appropriate communication with both the external and internal environment.

\section{Conclusion}

The basic condition for Polish Post to gain competitive advantage is the implementation of an effective and efficient system of communication with the market.
This is particularly vital in conditions of increasing competition on the postal market.

On the basis of reflection and analyses, the above thesis is shown to be true. Due to the low efficiency of traditional forms of communication with the market i.e. advertising, there is a need to seek new, more efficient and effective forms of communication. The issue of 
the effectiveness of the communication system is now extremely important, especially in a situation where the effectiveness and efficiency of traditional forms of communication - mass advertising - is decreasing. The measure of communication performance may be its efficiency, expressed by the ratio of the results of the effects of communication activities to the workload, or performance - determined by the perception of communication and its impact on the consciousness of buyers and the shaping of new attitudes and behaviors on the market.

In this paper, an analysis was made of select determinants of the effectiveness and efficiency of the communication system used by Polish Post, including the basic relationships between changes in the efficiency of the communication system and the following factors: market conditions, consumers and competitors. Such an approach enabled the search for answers on what and on whom depend the effectiveness and efficiency of the communication system.

The process of communicating specific value for the customer is closely linked with the dynamic transformation in the technical infrastructure of company communication with the market. Such factors as the emergence of the worldwide web and significant changes in the technology of information transmission have completely altered existing, traditional communication instruments and forms of promotion. Previously, the concept of communication only functioned in one direction; today it increasingly has to conform to an interactive marketing communication model. Therefore, companies (also the Polish Post) should not only attempt to pass a marketing message to consumers, but should also facilitate communication among their customers.

Postal communication is more effective and brings more benefits to the company if it is part of a coherent, long-term campaign aimed at enhancing the value of the brand. The recipient (receiver) of communication directs his attention to those messages that answer the question of what is in it for him. Each advertisement must be a promise. In the context of effective communication, consumers do not buy products - they buy benefits (satisfaction). The communication system will not be effective if it does not interest consumers. Any communication should be easily noticeable and original.

The communication system does not create needs they existed beforehand. The communication process should create a desire for specific products and services that can meet those needs. Value (benefits) that are not communicated will remain outside the realm of knowledge and awareness of customers; the communication process may prove to be ineffective.

According to the author, the analysis of the literature allows for a positive verification of the hypothesis that changes in today's business environment entail the need for effective action in terms of communicating customer value on the part of the company. With a proper communication system, one can build a positive image of company, gain credibility and confidence in dealing with the environment, and create better relationships with customers/ users of services. These are benefits which top management of Polish Post must think about.

\section{References}

Buko, J. (2007). Rola i aktywizowanie personelu pierwszego kontaktu w działalności pocztowej. Zeszyty Naukowe Uniwersytetu Szczecińskiego, 463: 530-531.

Buko, J. (2008). Powszechne usługi pocztowe jako szczególny rodzaj dóbr gwarantowanych przez państwo. Zeszyty Naukowe Uniwersytetu Szczecińskiego, 519: 251-252.

Cascio, W. F. (2005). From Business Partner to Driving Business Success: The Next Step in the Evolution of HR Management. Human Resource Management, 44 (2): 159-163.

Czarniewski, S. (2014). The Effectiveness of Communicating Customer Value. International Academic Research Journal of Business and Management, 3 (5): 10-28.

Dokurno, Z. (2008). Teoria endogenicznego wzrostu gospodarczego - próba systematyzacji i krytycznej analizy. Wroclaw: University of Economics in Wroclaw.

Gamble, P., Napp, A., Marsella, A., Stone, I.M. (2005). Marketing Revolution. Philadelphia: Kogan Page.

Gądek-Hawlena, T. (2003). Procesy dostosowawcze podaży na rynku ustug pocztowych w Polsce. Katowice: University of Economics in Katowice.

Gogołkiewicz, M. (2008). Wybrane rozwiązania technologiczne i organizacyjne stosowane przez europejskich publicznych operatorów pocztowych. Zeszyty Naukowe Uniwersytetu Szczecińskiego, 519: 630-631.

Kobus, R. (2009). Systemy informatyczne i elektroniczne w nowoczesnych usługach pocztowych. Zeszyty Naukowe Uniwersytetu Szczecińskiego, 544: 577.

Kotylak, S. (2008). Specyfika działalności państwowego przedsiębiorstwa użyteczności publicznej Poczta Polska w gospodarce rynkowej. Zeszyty Naukowe Uniwersytetu Szczecińskiego, 519: 346.

Kowalczyk, A., Nogalski, B. (2007). Zarzadzanie wiedza, koncepcja i narzędzia. Warsaw: Difin Publishing.

Kumar, V., Shah D. (2009). Expanding the Role of Marketing: From Customer Equity to Market Capitalisation, Journal of Marketing, 73 (6): 119-136. 
Labedz, C. S., Lee, J. (2011). The Mental Models of HR Professionals as Strategic Partners. Journal of Management and Organization, 17 (1): 56-76.

Lipowski, A. (2002). Ekonomiczna zawodność państwa krytyczna analiza ujęcia antyetatystycznego. Ekonomista, 2: 178-179.

Magdzicka, S. (2008). Wpływ rozwoju społeczeństwa informacyjnego na działalność operatorów pocztowych. Zeszyty Naukowe Uniwersytetu Szczecińskiego, 519: 241.

Martin, R. (2010). Age of Customer Capitalism. Harvard Business Review, 1/2: 58-65.

Mikołajczyk, Z. (2003). Zarządzanie procesem zmian $w$ organizacjach. Katowice: Silesian School of Economics.

Panasiuk, A. (2003). Rynek ustug pocztowych, marketing integracja. Szczecin: Polish Economic Society.

Pokora, W. (2008). Teoria efektywności działalności przedsiębiorstwa a praktyka Poczty Polskiej. Zeszyty Naukowe Uniwersytetu Szczecińskiego, 519: 451-452.

Report (2008). Raport Prezesa Urzędu Komunikacji Elektronicznej o stanie rynku ustug pocztowych w Polsce w 2007 roku, May: 13-14.

Rucińska, D. (2001). Marketingowe ksztattowanie rynku ustug transportowych. Gdansk: University of Gdansk.

Ryan, C. J. (2011). The Best Digital Marketing Campaigns in the World: Mastering The Art of Customer Engagement. London: Kogan Page Limited.
Šikýr, M. (2013). Best Practices in Human Resource Management: The Source of Excellent Performance and Sustained Competitiveness. Central European Business Review, 2 (1): 43-48.

Stańczak, K. (2008). Rynkowe zachowania Poczty Polskiej w warunkach społeczeństwa informacyjnego. Zeszyty Naukowe Uniwersytetu Szczecińskiego, 519: 527-528.

Stefanek-Dziadosz, A. (2009). Wpływ rozwoju społeczeństwa informacyjnego na kierunki zmian w Poczcie Polskiej. Zeszyty Naukowe Uniwersytetu Szczecińskiego, 544: 491.

Stolarczyk, A. (2006). Wpływ rozwoju technik komunikacji elektronicznej na rynek usług pocztowych w dobie tworzenia społeczeństwa informacyjnego. Telekomunikacja i Techniki Informacyjne, 3-4: 64.

Stolarczyk, A. (2007). Kierunki zmian na europejskim rynku usług pocztowych w świetle rozwoju technik ICT wybrane zagadnienia. Zeszyty Naukowe Uniwersytetu Szczecińskiego, 463: 370-372.

Author

Dr Sławomir Czarniewski University of Finance and Management in Bialystok UI. Ciepła 40

15-472 Białystok, Poland s.czarniewski@wp.pl 